\title{
FACTORS CAUSING ANXIETY IN SPEAKING ENGLISH EXPERIENCED BY THE STUDENTS OF SENIOR HIGH SCHOOL IN JOMBANG
}

\author{
Maisarah \\ Universitas Pesantren Tinggi Darul Ulum Jombang \\ Email: maisarah@fbs.unipdu.ac.id
}

\begin{abstract}
This study was conducted to know the factors contributing to the anxiety in speaking English experienced by students of a high school in Jombang. This study identified the factors of anxiety in speaking English based on the phenomenon experienced by the students. The research method used in this study was descriptive quantitative. Ten students who felt anxious in speaking were chosen as respondent based on the results of the questionnaire from preliminary study. The research instruments used in the data collection was questionnaire. While the data analysis was the frequency distribution analysis (percentage of occurrence). The result shows that there were three factors that cause anxiety in speaking the factors were: communication apprehension, test anxiety, and negative evaluation. The results of this study showed that the first factor had the most influenced on students' anxiety in speaking English was the communication apprehension which was the strongest factor causing the students' anxiety in speaking. The second was the test Anxietyand the last one is the fear of being evaluated negatively.
\end{abstract}

Keywords: Speaking Skill, Speaking Anxiety, and English as EFL

\begin{abstract}
Abstrak
Penelitian ini dilakukan untuk mengetahui faktor-faktor yang berkontribusi terhadap kecemasan berbahasa Inggris yang dialami oleh siswa sekolah menengah di Jombang. Penelitian ini mengidentifikasi faktor-faktor kecemasan dalam berbicara bahasa Inggris berdasarkan fenomena yang dialami oleh siswa. Metode penelitian yang digunakan dalam penelitian ini adalah deskriptif kuantitatif. Sepuluh siswa yang mengalami kecemasan dalam berbicara dipilih sebagai respon den berdasarkan pada hasil kuesioner dari studi pendahuluan. Instrumen penelitian yang digunakan dalam pengumpulan data adalah kuesioner. Sedangkan analisis data adalah analisis distribusi frekuensi (persentase kejadian). Hasil penelitian menunjukkan bahwa ada tiga faktor yang menyebabkan kecemasan dalam berbicara: ketakutan komunikasi, kecemasan tes, dan evaluasi negatif. Hasil penelitian menunjukkan bahwa factor pertama yang paling mempengaruhi kecemasan siswa dalam berbicara bahasa Inggris adalah communication apprehension yang merupakan factor terkuat yang menyebabkan kecemasan siswa dalam berbicara. Yang kedua adalah test Anxiety dan yang terakhir adalah negative evaluation.
\end{abstract}

Kata Kunci: Speaking Skill, Speaking Anxiety, dan English as EFL 


\section{A. Introduction}

Speaking is one of the main subjects taught in Indonesian Senior High Schools. Speaking is a skill that requires learners to produce language in communication. Moreover, speaking skill is a priority for the most English Language Teaching (ELT). The goal of English speaking is to make students acquire the ability to use English vocabulary, grammar, pronunciation, and intonation fluently. In other words, it can be said that speaking skills is a complex skill. This complexity of speaking skills make students difficult to improve their abilities in speaking.

In addition, the increase of using English has led students to be required to learn good communication skills. A good communication has relationship with the fluency of student's communication in foreign language. To have such abilities, students have to have high self-confidence and ability in mastering the foreign language. Therefore, to master a foreign language, students should be able to speak confidently.

Horwitz and Cope's cited in Trang (2012) that there are some obstacles that often hinder the students' fluency which not only emerge from teachers (external aspects) but also from the learners themselves (internal aspect). On the other hand, Brown (2000: 150-153) stated that English has been taught as a foreign language in countries where the people do not use English as "their major language education". In Indonesia, English is a compulsory subject taught in high schools.

Unfortunately, many students felt anxious and nervous when speaking English. Having communication in a foreign language can be a stressful activity for them since they have to speak the language which is not their first or mother tongue.Some studies conducted by experts also showed that speaking is the greatest activity that stimulates anxiety by most of foreign language learners Maclntyre and Grdner cited as in Maturanec.I (2015: 11-14).

Such phenomenon was also experienced by students in MA (Senior High School) in Jombang. Some students seemed to experienceanxiety in speaking English. Some students seemed to speakunconfidently.Some were afraid to be asked to speak, and others even looked sweaty and tremble. Because of that this 
research was conducted to see the factors causing anxiety to speaking English experienced by the students. By identifying the factors underlying their anxiety, the result is useful for formulating appropriate strategy to apply when teaching speaking. The students were those who experienced anxiety in speaking English.

\section{B. Literature Review}

Anxiety in speaking is the most frequently cited concern by foreign language learners who can negatively affect their performances and abilities to process information in the target language, Mak and Liu cited in Ahmed (2016:99). Lanerfeldt (2011:4) described that the anxiety of speaking as something that has a great impact on one's confidence because it often makes persons fail when unable to speak and show what someone knows. Speaking anxiety as a fear of expressing oneself verbally can be recognized by psychology signs such as irregular heartbeat, sweating, stumbling and an inability to act some of the symptoms that hinder the ability to act and speak, Mitchell dan Myles cited in Tasnimi (2009:18-119). There are three factors of anxiety in speaking English as already stated by Horwitz, Horwitz and Cope (2012).

1. Communication Apprehension

Horwizt and et al, (2012) stated that communication apprehension is a type of shyness characterized by fear, anxiety about communicating with people or difficulty speaking in groups and oral communication in public (stage fright). Lucas et al, (2011) stated that communication apprehension characterized by fear and anxiety in communicating with people and difficulty in speaking in public, listening or learning a spoken utterance are all manifestations of communication apprehension. This type of anxiety in learning a second language is derived from the learners' personal knowledge that they will have difficulty in understanding others and made themselves understand.

2. Test-Anxiety

Test anxiety refers to a type of performance anxiety stemming from a fear of failure Horwizt and et al, (2012). Test-anxious students often put unrealistic demanding on themselves and feel that anything less than a perfect test 
performance is failure. Students who are test-anxious in foreign language class perhapsundergosubstantial difficulty as tests and quizzes are repeated and even the best and most equipped students often make errors and that is faced by the anxious learners when taking formal test or other evaluative situations.

3. Fear of Negative Evaluation

Fear of negative evaluation is the apprehension about other peoples' evaluations Horwizt et al, (2012). This may also involveescaping of evaluative situations and the expectations that others might evaluate them negatively. It may also include the student's fear inside the English classroom where factors such as learning activities, teacher's methodology and even peer pressure may contribute to novice language learners' anxieties or as apprehension about others' evaluations, avoidance of evaluative situations, and the expectation that others would evaluate oneself negatively.

\section{Method}

This research applied a descriptive quantitative. The respondents of this research were ten students of grade XII, who experienced speaking anxiety. The respondents were selected based on the fact that they really experienced speaking anxiety as evidenced by their responses on the first questionnaire distributed to them before the lesson began. The data in this research were in forms of student' responses related to speaking anxiety. The source of the data was the student' answers related to anxiety or any responses from the students concerning the causes of their anxiety taken from the result of questionnaire.

To collect the data, this research used questionnaires. There were two questionnaires. The first questionnaire consisted of questions related to speaking anxiety. The aim of the questionnaires was to select the respondent of the research. There was one question that hadto be answered by the respondents. The questions were "Do you felt nervous or anxious when you asked or was speak English in front of class? The second questionnaires given to the respondentswere based on the first questionnaires. The purpose of these questionnaireswas to 
explore more about the factors causing speaking anxiety in English experienced by the respondent of senior high school. The questionnaires consisted of 10 questions. Generally, the questions divide into three causes of topic: (1) Communication Apprehension (2) Test Anxiety (3) Negative Evaluation. There were four questions in Communication Apprehension, three questions in Test Anxiety, and three questions in Negative of Evaluation. After the data were collected the following steps of data analysis were applied:

1. Explaining the data quantitatively based on three main causes of speaking anxiety. The quantitative analysis used the frequency distribution method with the following formula:

$$
\begin{aligned}
& \mathrm{n} / \mathrm{N} \times 100 \\
& \mathrm{n}=\text { respondents who answered 'yes' } \\
& \mathrm{N}=\text { total number of respondents }
\end{aligned}
$$

2. Explaining the data quantitatively based on the respondents' reasons of each factor. The quantitative analysis used the frequency distribution method with the following formula: $\mathrm{n} / \mathrm{N}$ x 100

$\mathrm{n}=$ respondents who answered the same reasons

$\mathrm{N}=$ total number of respondents who answered 'yes'

\section{Result}

Based on the results of data analysis the factorsof communication apprehension, anxiety test, and negative evaluation were the factors causing anxiety in speaking English.

\section{Communication apprehension factor}

a. Students' responses on the first question of communication apprehension factor

For the question, "Do you tend to avoid when someone asks you to converse in English?" Most respondents (90\% percent) answered "yes". In general, this occurred because they did not have high proficiency in speaking English (44.4\% percent). Besides there are several other factors that make the students tend to avoid when they are asked to speak English such as: The students had no interest in English (22.2\% percent); They had 
limited vocabulary in English (22.2\% percent); and They were afraid of not understanding what was being said and unable to answer in English (11.1\% percent).

b. Students' responses on the second question of communication apprehension factor

The responses from the respondents to the question "Are you shy or afraid while communicating in English with your friends?" Most respondents (90\% percent) answered "yes" to this question. In other words, they felt shy and afraid when communicating in English with other friends. Commonly, this occurs because they assumed that their English language skill was lower than their friends whom they talked to $(44.4 \%$ percent). Besides their shyness and fear of speaking were due to other factors such as they thought that they could not speak English well (22.2\%); they were shy and afraid of making mistakes when speaking in English (11.1\%); They were not confident (11.1\%); and they had no enough vocabulary for speaking (11.1\%).

c. Students' responses on the third question of communication apprehension factor

The majority of respondents $(90 \%)$ had difficulty delivering messages in English. This can be seen from their responses to the question "Do you have difficulty conveying messages to your friends or other people in English?" Most respondents (90\% percent) answered "yes" to this question. The reason underlying their difficulty were they could not speak English (33.3\%). Besides they had limited vocabulary (22.2\%); They had difficulty choosing the right words (22.2\%); They were not accustomed to speaking English everyday (11.1\%); and They could not understand what to say in English (11.1\%).

d. Students' responses on the fourth question of communication apprehension factor

To the question "Do you often have difficulty understanding the conversation of others in English?" 8 out of 10 respondents (90\%) said "yes". The reasons underlying their answers were that they did not have a 
lot of English vocabularies (44.4\%). The other reasons why they had difficulty understanding the conversations of others in English were that the students had difficulty understanding English words (22.2\%); the pronunciation and writing of English words were not the same so that they had difficulty guessing and understanding them (22.2\%); and assuming that English lessons was difficult to understand and were not used to speak English.

\section{Test anxiety factor}

a. Students' responses on the first question of test anxiety factor

To the question "Are you afraid or anxious when facing an English exam?" Most respondents (70\%) answered "yes". In general, this happened because they did not understand the meaning when speaking in English (42.8\%). Besides there were some other factors that made them tend to feel afraid or anxious when facing English exam. They were afraid of getting bad score (28.5\%); fear of making mistake (14.2\%); and considering that English is difficult lesson (14.2\%).

b. Students' responses on the second question of test anxiety factor

From the table result, it can be seen that that most respondents answered "yes" (70\%) to the question "Do you feel afraid or anxiety of facing speaking test in front class?" It mostly occurred because they were afraid of making mistakes $(57.1 \%)$. The other reasons causing their fear and anxiety of facing speaking test were they assumed that they had low ability in speaking English (28.5\%); they felt afraid of being laughed by other friends in class (14.2\%); and they felt nervous when facing speaking test in front class $(14.2 \%)$.

\section{Negative evaluation factor}

a. Students' responses on the first question of negative evaluation factor

For the first question "Do you feel afraid of making mistakes each time being asked to speak in front the class." Out of the 10 students, $60 \%$ students answered "yes". In sum, it shows that most students were afraid of making mistakes each time being asked to speak in front of the class. This happened due to several factors such as:They were afraid of making 
mistakes in pronunciation when speaking English (33.3\%); They had limited English vocabulary (33.3\%); They felt nervous (16.6\%); and They were afraid to get a bad score from teachers $(16.6 \%)$.

b. Students' responses on the second question of negative evaluation factor

For the second question "Do you often feel afraid or anxious if the teacher will assess your speaking skills with bad score?" The result showed that $60 \%$ students answered "yes".In general, this was because they often felt afraid and anxious if the teachers and classmates would assess the students' speaking ability negatively (getting bad score) (50\%). Besides, there were another factors that caused this namely they could not speak English (33.3\%); and they assumed that their English ability was poorer than others $(16.6 \%)$

c. Students' responses on the third question of negative evaluation factor

And for the third question "Do you often feel afraid of being laughed by your other friends when you speak and make mistakes in front of class?", $60 \%$ respondent responded "yes" which means that they were afraid of being laughed by other friends when speaking English and making mistakes in front of the class. Meanwhile, there were other cases causing this. They were they were shy if he/she incorrectly spoke in English in front of class (33.3\%); they assumed that their ability was poorer than others $(33.3 \%)$; they could not speak English (16.6\%); and they were afraid to get bad score (16.6\%.)

\section{E. Discussion}

Horwitz, Horwitz and Cope (2012) said that there were three factors causing anxiety in speaking. The factors were: communication apprehension, test anxiety, and negative evaluation. In fact these three factors caused the respondents' anxiety in speaking and almost all of the respondents experienced them. For the first factor, communication apprehension, most respondents (90\%) experienced it. The respondents' responses could be summarized in the following table: 
Table 1 Respondents' Responses Concerning Communication Apprehension

\begin{tabular}{|c|l|}
\hline 1 & Not having high proficiency in speaking English \\
\hline 2 & Having no interest in English \\
\hline 3 & $\begin{array}{l}\text { Afraid of not understanding what was being said and unable to answer in } \\
\text { English }\end{array}$ \\
\hline 4 & Having limited vocabulary in English \\
\hline 5 & Thinking that they could not speak English well \\
\hline 6 & Shy and afraid of making mistakes when speaking in English \\
\hline 7 & Being not confident \\
\hline 8 & $\begin{array}{l}\text { Assuming that their English language skill was lower than that of their friends } \\
\text { whom they talked to }\end{array}$ \\
\hline 9 & Having difficulty choosing the right words \\
\hline 10 & Not accustomed to speaking English everyday \\
\hline
\end{tabular}

Source: Interview with Respondents. 2018

From these responses, we can see some of the main reasons that led to the communication apprehension: They had no high proficiency in speaking English; they had limited vocabulary; and they were afraid to speak in English.

The three reasons made them discouraged to speak in English. They tended to be anxious when they were asked to speak in English. The Anxiety appeared especially before and during the process of speaking. It then influenced their fluency in speaking. As a result they tended to speak unclear of the direction. This anxiety created a feeling of distress that made them doubtful whether they could successfully deliver their messages or not. In short, anxiety to speak English experienced by the students was mainly caused by the factor of communication apprehension. For the second factor, test anxiety, most respondents also experienced this. The respondents' responses that indicated they experienced this were asfollows:

Table 2 Respondents' Responses Concerning Test Anxiety

\begin{tabular}{|l|l|}
\hline 1 & Not understanding the meaning of English words or expressions \\
\hline 2 & Afraid of making mistakes \\
\hline 3 & Afraid of getting bad score \\
\hline 4 & Students consider that English is difficult lessons \\
\hline 5 & Afraid of being laughed by other friends in class \\
\hline 6 & Nervous \\
\hline 7 & Having low ability in speaking English \\
\hline
\end{tabular}

Source: Interview with Respondents. 2018

Test anxiety based on the analysis of the respondents was the second influential factor causing the respondents' speaking anxiety. The reasons why 
they experienced test anxiety were thinking that they had low English proficiency, nervousness, fear of getting bad scores, afraid of being laughed and fear of making mistakes during speaking test. Out of the seven reasons, the underlying reasons causing their test anxiety were their fear of getting bad score and being laughed by the others. This kind of fear was principally stemmed from their low English proficiency. In short we can say that the factor of test anxiety contributed significantly to their anxiety of speaking. For the third factor, a negative evaluation, most $(60 \%)$ experienced this. The signs (the respondents' responses that indicated this were):

Table 3 Respondents' Responses Concerning Negative Evaluation

\begin{tabular}{|l|l|}
\hline 1 & Feeling nervous \\
\hline 2 & Afraid of making mistakes in pronunciation when speaking English \\
\hline 3 & Shy if he/she spoke English incorrectly in front of class \\
\hline 4 & Having limited English vocabulary \\
\hline 5 & $\begin{array}{l}\text { Afraid and anxious if the teachers and classmates would assess his/her } \\
\text { speaking ability with bad score }\end{array}$ \\
\hline 6 & Assuming that their ability was poorer than the others' \\
\hline
\end{tabular}

Source: Interview with Respondents. 2018

Based on the analysis of the students' responses, this third factor (negative evaluation) contributed to their anxiety of speaking. Commonly the reasons why they experienced this were due to their self-evaluation that they had low proficiency in English including limited English vocabulary. This main reason then contributed to their fear of being evaluated poorly by the teacher and their classmates. They also became nervous when they were asked to perform speaking in front. This negative assessment is as a result that they were afraid of failing to satisfy the expectation of a "good show" in front of their friends.

They were afraid to perform in class because they thought their classmates and the teacher would assess them negatively every time they performed. Again this was mainly caused by their low English speaking skill, lack of vocabulary, fear of making mistakes in pronunciation, and their shyness. In short, their anxiety of speaking was as a result of the factor of negative evaluation.

\section{F. Conclusion}

Based on the result of analysis, it can be concluded that: First, there were some factors causing the anxiety of XI grade of the students in speaking English. 
Almost all respondents experienced the three factors. They were: communication apprehension, test anxiety, and the fear of having negative evaluation from other people. Second, the factor of communication apprehension obtained $90 \%$. It was considered as the strongest factor causing the students anxiety among other factors. It was caused by the low ability of the respondents and their feelings that the other people had better ability of communication. It was also caused by the limited vocabulary and the fear of speaking in English.

\section{References}

Ahmed, N. F. 2016. An Exploration of Speaking Anxiety with Kurdish University EFL Learners.Journal of Education and Practice, Soran University.Vol.7, No. 27, 99. Retrieved 17 June 2017 from; Available at URL; (http://iiste.org/Journals/index.php/JEP/article/viewFile/33211/34109/availa ble:17/ June/ 2017).

Aida, Y. 1994. Examination of Horwizt and Cope's Construct of Foreign Language Anxiety: the case of students of japanese. The Modern Language Journal. Vol.78 No. 2. Retrieved 15 June 2017 from; Available at URL; (http://www.academia.edu/2498042/Examination_of_Horwitz_Horwitz_and Copes_construct_of_foreign_language_anxiety_The_case_of_students_of_ Japanese.).

Brown, H. D. 2000. Principles of Language Learning and Teaching. (4 ${ }^{\text {th }}$ ed.). San Francisco: Longman.

Hamm,P.H. 2006. Teaching and persuasive Communication : class prensentation skills.. Brown University; The Harriet W. Sheridan Center. P.10-12.

Horwizt, E. K., Horwizt, M. B., \& Cope, J. 2012. Foreign Language Classroom Anxiety. The Modern Languange Journal, Vol. 70, No. 2, 125-132. Retrieved 15 June 2017 from; Available at URL; (http://hyxy.nankai.edu.cn/jingpinke/buchongyuedu/foreign $\% 20$ language $\% 2$ 0classroom\%20anxiety.pdf.).

Lanerfeldt, M. 2011.Speaking anxiety; an obstacle to second language learning.University: Hoskolan I Gavle p.53-54. Retrieved 15 June 2017 from; Available at URL;

(https://www.diva.portal.org/smash/get/diva2:453921/fulltext01.pdf.).

Lucas, R. I., Miraflores, E., Go, D., \& Salle, D. L. 2011. English Languange Learning Anxiety among Foreign Language Learners in the philippines.Philippine ESL Journal, Vol. 7. De Manila: La Salle University. Retrieved 15 June 2017 from; Available at URL; (https://www.philippineesl-journal.com/wp-content /01/V7-A5.pdf.).

Maturanec, I. 2015. Foreign Language Anxiety : Interaction with gender, Length of study and self perception of competence. University of Zagreb. Retrieved 15 June 2017 from; Available at URL; 
(http://darhiv.ffzg.unizg.hr/5721/1/Foreign\%20language\%20anxiety\%20\%2 Ointeraction $\% 20$ with $\% 20$ gender $\% 2$ C $\% 20$ lenght $\% 20$ of $\% 20$ study $\% 20$ and $\% 2$ 0self-perception $\% 20$ of $\% 20$ competence.pdf.).

Muhson. A. 2011. Teknik Analisis Kuantitatif. Penyajian Data dalam Bentuk Tabel. Retrieved from; 1 July 2017. Available at URL;

(http://statistikdasar.com/files/materi/penyajian_data_dalam_tabel.pdf).Cite d on (1 St July 2017: p.2).

Mukminin, A., Noprival, Masbirorotni, Sutarno, Arif, N., \& Maimunah. 2015. Speaking Anxiety among Senior High School Students and Policy Recommendations . Journal of Education and Learning, Vol. 9(3), pp.217225. Jambi University. Retrieved 15 June 2017 from; Available at URL; (http://journal.uad.ac.id/index.php/EduLearn/article/viewFile/1828/pdf_93.).

Musthachim, A. 2014. Students' Anxiety in Learning English (A Case Study at the $8^{\text {th }}$ Grade of SMPN9 South Tangerang. Jakarta: Islamic University Syarif Hidayatullah. Retrieved 9 Juli 2017 from; Available at URL; (http://Repository.Uinjkt.Ac.Id/Dspace/Bitstream/123456789/26300/3/Angg iyana\%20musthachim-Fitk.Pdf,/ available: 9/ July/ 2017.).

Oktaviana, F. S. 2013. An Analysis of Students' English Language Anxiety at SMAN 7 PADANG.University of Padang. Retrieved 9 JuI 2017 from; Available at URL;

(http://download.portalgaruda.org/article.php?article=100277\&val=1486.).

Richards, J. 2008 Teaching speaking theories and methodologies; English language teaching. Retrieved 15 June 2017 from; Available at URL;

(http://old.fltrp.com/download/080403001.pdf.).

Tanveer, M. 2007. Investigation of the factors that cause language anxiety for ESL/EFL learners in learning speaking skills and the influence it casts on communication in the target Language. Glasgow: University of Glasgow. Retrieved 15 June 2017 from; Available at URL;

(https://www.researchgate.net/publication/293263722.).

Tasnimi, M. 2009. Affective factors: Anxiety. Islamic Azad University. Journal of Pan- Pacific Association of Applied Linguistics, 13(2), 117-124.

Trang, T .T. 2012. A Review of Horwitz, Horwitz and Cope's Theory of Foreign Language Anxiety and the Challenges to the Theory. Journal English Language Teaching, Vol. 5, No.1; Available at URL;

(http://www.ccsenet.org/journal/index.php/elt/article/viewFile/13878/9524.).

Zheng, Y. 2008. Anxiety and Second/Foreign Languange Learning .Canadian Journal for New Scholars in Education, Vol. 1. Queen's University. Available at URL;

(https://journalhosting.ucalgary.ca/index.php/cjnse/article/view/30393/2483 5/ available: 17/June/ 2017). 